\title{
What Ancient Christian Manuscripts Reveal About Reading (and About Non-Reading)
}

For a contribution on key aspects of reading in the various book-based religions of antiquity and their religious groupings, to look at non-reading probably sounds like something of a paradox. Too often however, we have become accustomed (as the term "book-based religion" itself shows) to regarding ancient Jewish, Christian and Muslim communities as first and foremost textual communities i.e. as religious communities which, according to Brian Stock's definition "came to understand their identities through the mediation of written texts, which often were interpreted for them by key individuals." Images of "textual communities" from Jewish, Christian and Muslim life spring to mind immediately: readings during the mass, the liturgical veneration of the book during Christian and Jewish worship, exegesis in Jewish synagogue sermons and Christian homilies, commentaries in Biblical books based on the ancient Alexandrian or Pergamenian commentary technique, excerption, citation, the paraphrasing of biblical texts in various genres, the compilation of lemmatised anthologies such as the Byzantine chain commentaries, the catenae. ${ }^{2}$ Besides as textual communities, we also have a tendency to regard the three more or less monotheistic religions (to use, for the sake of simplicity, a term from modern religious studies that is far from unproblematic) of late antiquity as reading communities, as an accumulation of reading circles and of networks circulating reading matter. Religious communities such as in Qumran, monastic movements like the Pachomian abbeys, institutions of higher learning like the Private University of the first Christian polymath Origen in Caesarea Maritima and of course the ancient Christian synods and councils too were, at least in our minds, not just textual but also very much reading communities. That the same Origen in his sermons, which he gave to a house community comprising about thirty members in the late 30 s and 40 s of the fourth century somewhere near the port of Caesarea Maritima, repeatedly called upon his audience to read up on the biblical texts he was referring to is another example of the existence of both a textual and a reading community. ${ }^{3}$ At a synod in the fourth century, to which guests were invited from throughout the empire to discuss problems with Trinitarian theology for example, it is documented that, naturally in the back rooms and during breaks in proceedings, those taking part grappled to arrive at common explanations-usually in the form of what were known as credos. Text drafts, which were also subject to intense discussion, were circulated at these and also significantly amended. In order to do this, it

1 Stock 1983.-On Christian books and readers in general cf. Gamble 1995 and Nongbri 2018.

2 Kannengiesser 2004 and Markschies 2004, 77-88.

3 Markschies 2007, 35-62.

Ә Open Access. (C) 2020 Christoph Markschies, published by De Gruyter. (c) BY-NC-ND This work is licensed under the Creative Commons Attribution-NonCommercial-NoDerivatives 4.0 License.

https://doi.org/10.1515/ 9783110639247-012 
was imperative that they should be read by individuals or read aloud to groups of course. Some time ago I retraced these procedures in greater detail for a lesser known imperial council-the synod of Sirmium in 359 AD. ${ }^{4}$ For our purposes today however, a simple reference to what Stock calls "textual communities" and the importance of certain bishops as "key individuals" will suffice. In this respect we can scarcely doubt that worship-based communities like that of Origen in Caesarea Maritima or ancient Christian synods represent, at least for our purposes, the close relationship between "textual communities" and "reading communities", something which appears to have been not just a characteristic of ancient Christianity.

But is this picture to which we have become accustomed a true one? In the first part of my address this evening, I shall propose a description of the behavior of many ancient people that is loosely based on a rhetorical idea by St. Paul the apostle: ${ }^{5}$ having books as if they did not have them, reading as if they did not read. A consideration of the key aspects of the ancient written tradition leads to this what is, at first sight, somewhat absurd or at least surprising conclusion. To begin with, we have become accustomed to arriving at conclusions on the scope and social structure of Christianity as a reading community during antiquity from its well documented preference for the codex, both sides of which could be written on, consequently not only offering more space for text than scrolls, which could only be written on one side, but being less expensive too. It is commonly believed-as documented by Theodore C. Skeatthat the religion empowered people from social strata who, due to their humble socio-educational backgrounds, were unfamiliar with scrolls and the reading thereof, to take advantage of the more affordable codices. ${ }^{6}$ Even allowing for William V. Harris however, in particular bearing in mind the greater legibility of the codex as the reason for its rapid spreading within Christian communities, ${ }^{7}$ we still cannot get away from the traditional impression of particularly large Christian "reading communities" coming from a wide range of social strata. Even taking into account, as Harris does that, with the conventional pattern of decline in late antiquity, the number of copies of pagan literary texts decreased from the fourth century onwards and the significance of books for the spreading of Christianity is overestimated, ${ }^{8}$ clichés like that of a "bookbased religion" nevertheless pertain.

To argue against the use of such clichés, I would first like to make reference to a text genre that receives scant attention these days that was hitherto primarily assessed in the history of theology-lists of bishop signatories from the ancient synods and imperial councils. Signatures gleaned from these allow us to draw conclusions about the reading abilities of bishops who attended the councils. Looking at this matter further,

4 Markschies 2017a, 111-130.

5 In 1. Cor. 7:29.

6 Roberts/Skeat 1983.

7 Harris 1989, $295 f$.

8 Harris 1989, $298 f$. 
the Greek records of the imperial council of Ephesus in $431 \mathrm{CE}$ (known to be just one of the two bishops' conferences that took place simultaneously in the Asian metropolis) presided over by Bishop Cyril of Alexandria includes a list of signatures with 197 names of bishops who condemned the teachings of the Patriarch of Constantinople, Nestorius, the supporters of whom had gathered at the same location in the Asian metropolis for the aforementioned opposing council. The complex handing down of the records, which were arranged for us by Eduard Schwartz (and after him Thomas Graumann), ${ }^{9}$ of course constitutes a mediaesque attempt on the part of Bishop Cyril's party to cast the scandalous story of the subcouncil in a favourable light.

The Latin translation of the records from the imperial council of Ephesus in 431 CE led by Bishop Cyril, for instance, contains an attendance list with the names of 193 bishops who condemned the teachings of the Patriarch of Constantinople, Nestorius, the supporters of whom assembled at the same location in the Asian metropolis in order to form a counter council. Although the Latin translation of the records only contains a list of 193 signatures, the findings are similar. As well as typical information such as "Cyril, Bishop of Alexandria: I have signed", ${ }^{10}$ the list contains in some places the statement "Signed on my behalf by the presbyter" (followed by the name of the presbyter or other lower level dignitary such as: "Archdeacon of Aetherius"). ${ }^{11}$ As well as presbyters i. e. priests who accompanied the bishops, there are also signatures by their counsellors (notarii) and in one case, due to illness, by a bishop from a neighbouring town. Since a special note is made of this illness, the proxy signatures on the part of others can only be an indication of the large number of Illiterati and analphabets in the kingdom at the time, which is estimated to have been more than sixty percent. ${ }^{12}$ In one version of the list of signatures handed down to us, this is also stated explicitly for one bishop whom we will take a look at in greater detail in a moment: "Aetherius, Archdeacon, has signed on his (i. e. the bishop's) behalf because he could not read and write". ${ }^{13}$ In other words, bishops who had a deacon, archdeacon, presbyter or notarius sign on their behalf, were presumably not able to write. But just how many of the two hundred bishops who supported the polemical patriarch Cyril of Alexandria were not able to write? In the list of the 197 or 193 names of bishops who signed the records at the (sub-)council of Bishop Cyril of Alexandria's followers in

9 Meier (2011), 124-139 and Graumann 2002, 349-392.

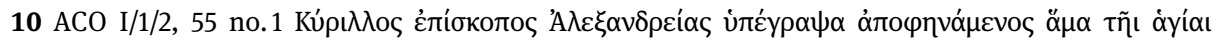

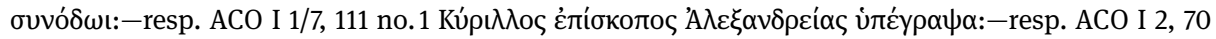
no. 1 Cyrillus episcopus Alexandriae subscripsi pronuntians cum sancta synodo. For the whole procedure cf. Weckwerth 2010, 1-30.

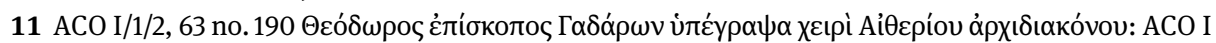

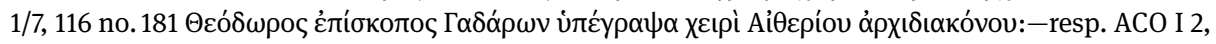
74 no. 181 Theodorus episcopus Gadaron subscripsi manu Aetherii archidiaconi.

12 Brown 1993, 26 f or 1995, 53.

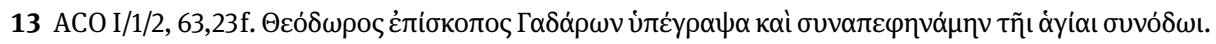

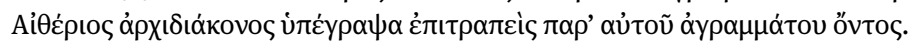


Ephesus in $431 \mathrm{CE}$, out of the names of the 193 bishops listed, only a handful needed a proxy signature by a presbyter or counsellor yet, looking more closely at the details, we nonetheless find something remarkable. For, among the bishops unable to write is Theodorus of Gadara, a city located to the south-east of the Sea of Galilee (modern day Um Qeis, directly on the Jordanian/Israeli border). Theodorus has his archdeacon

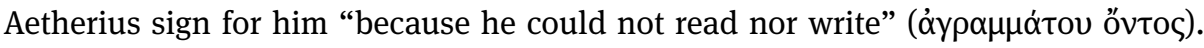
If the written records handed down to us do not deceive, he was not yet present on the day the council, which was brought forward, was opened (or at least he is not included in the list of the one-hundred and fifty-five bishops in attendance at the opening). ${ }^{14}$ However, the synod participant in question is by no means an entirely uneducated person incapable to follow the proceedings: The Bishop of Gadara was in fact one of a series of one hundred and twenty five bishops who attested the concordance of a text by Cyril of Alexandria with the confession of the fathers from the first imperial council of Nicaea in $325 \mathrm{AD}$. According to the evidence in the records he said: "For the letter by the most holy and venerable Bishop Cyril that was read out is of sound content and pious and concords with the symbol of the faith recorded by the Holy Fathers who convened in Nicaea. I too concur with this". ${ }^{15}$ Evidently, he could not write but nonetheless followed the proceedings ably and was theologically qualified to express himself (i. e. as a follower of Cyril, Bishop of Alexandria). At the council, he also rose to speak once again towards the end, presuming we can trust the reliability of the records-to attest that Cyril's arch enemy, Bishop Nestorius (who presided over the other subcouncil), unlike Cyril, did not obey the confession of the fathers of Nicaea. ${ }^{16}$

The fact that the Bishop of Gadara was not only unable to read and write but also that this fact is recorded explicitly in the synodal records is surprising in light of the level of culture in his episcopal seat south of Lake Galilee: As not only excavations and other sources have shown that Gadara was a larger city with considerable prosperity and a high level of education: ${ }^{17}$ One inhabitant was Menippus, who invented the satire to which he gave this name and who was also a cynical philosopher, ${ }^{18}$ as well as the author of epigrams Meleager-who penned the encomiastic lines "Island Tyre was my nurse, and Gadara, an Attic fatherland which lies in Assyria gave birth

14 ACO I $1 / 2,3-7$.

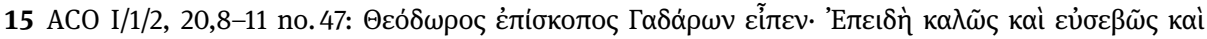

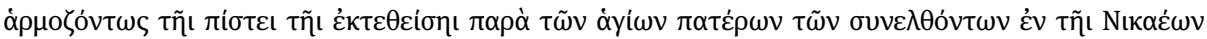

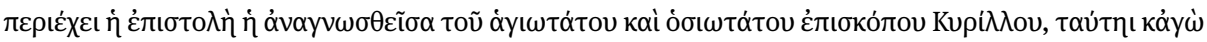

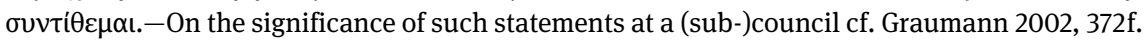

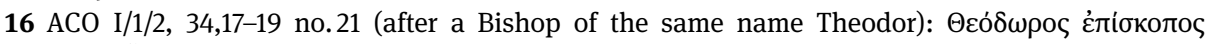

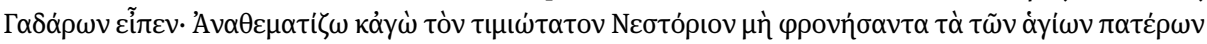

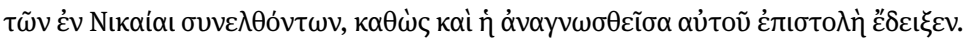

17 Weber 2002, passim.

18 Döring 1998, 311. 
to me." ${ }^{19}$ Meleager also makes an explicit reference to the city's greatest son: "From Eucrates I sprung, Meleager, who first by the help of the Muses ran."20 Some time later, the Roman rhetorician and historian Theodorus of Gadara, who taught the later Roman Emperor Tiberius between 33-30 BC (so well that the latter could hold a funeral oration for this biological father Tiberius Claudius Nero at the age of just nine $)^{21}$

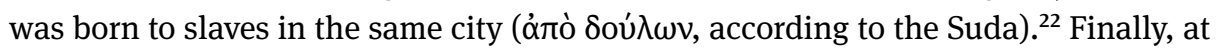
the start of the second century AD, the cynic philosopher Oenomaus, the author of a book opposing the oracles said by Eusebius to have been called "The Swindlers Unmasked" (Гoń $\tau \omega \nu ~ \varphi \omega ́ \rho \alpha)^{23}$ and who also appears several times in Midrash Bereshit Rabba and in other rabbinic texts as Abnimos ha-Gardi, was active in the city. ${ }^{24}$ Considering this list, which is still very much incomplete, it is somewhat remarkable that the bishop of the Christian community of this city in the fifth century was apparently unable to write. This was clearly no obstacle to his being elected bishop, nor any reason for him to keep a low profile at the subcouncil of Cyril of Alexandria's followers in Ephesus in $451 \mathrm{CE}$, skulking about in the background.

One well-known example from the preceding fourth century also speaks for the interpretation that illiteracy in no way hindered a career in the Christian church. Even if we in the meantime think we know that St Anthony, the founder of anachoretic monasticism, could read and write well (letters on theological matters have been handed down that were in all likelihood written by him), he was nonetheless portrayed in late antiquity as illiterate. ${ }^{25}$ Athanasius, a famous predecessor in Cyril of Alexandria, in

\footnotetext{
19 Anthologia Graeca VII 417:

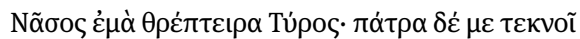

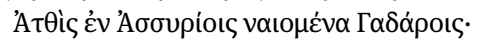

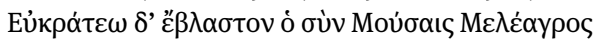

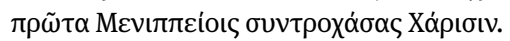

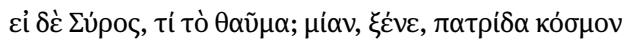

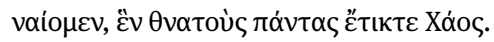

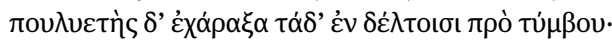

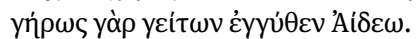

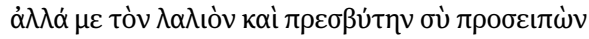

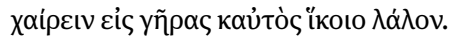

20 Anthologia Graeca VII 417.
}

21 Sueton, Tiberius 6. 57.

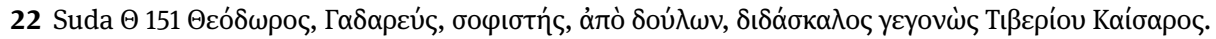

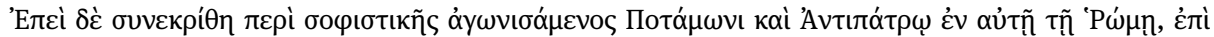

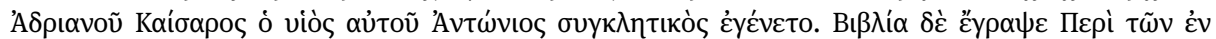

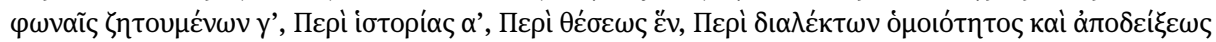

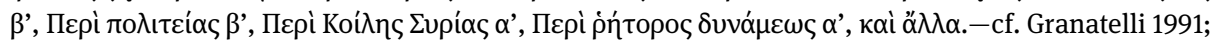
Grube 1959, 337-365.

23 Hammerstaedt 1988, 33-47.

24 Hammerstaedt 1988, 11-19.

25 Rubenson 1998, 95-99. 


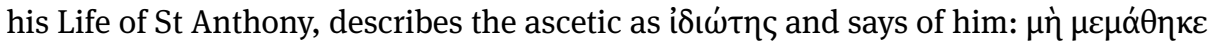
ypó $\mu \mu \alpha \tau \alpha .^{26}$ Like many other Christians in late antiquity, this image of St Anthony as conceived by Athanasius had a deep impression on the North-African Bishop Augustine, as his Confessiones show yet he nevertheless wrote in the prologue to his hermeneutics De doctrina Christiana Augustine states:

\begin{abstract}
But now as to those who talk vauntingly of Divine Grace and boast that they understand and can explain Scripture without the aid of such directions as those I now propose to lay down, and who think, therefore, that what I have undertaken to write is entirely superfluous. I wish such persons could calm themselves so far as to remember that, however justly they may rejoice in God's great gift, yet it was from human teachers they themselves learnt to read. Now, they would hardly think it right that they should for that reason be held in contempt by the Egyptian monk Anthony, a just and holy man, who, not being able to read himself, is said to have committed the Scriptures to memory through hearing them read by others, and by dint of wise meditation to have arrived at a thorough understanding of them. ${ }^{27}$
\end{abstract}

Augustine therefore excused quasi the inability of St Anthony to read and write, which he could not help but assume due to his reading of the Latin translation of Athanasius' Vita by the fact that the ascetic knew the scripture by heart anyway, even without any knowledge of such cultural techniques. The truth about the reading and writing skills of St Anthony however and whether-like Bishop Theodorus of Gadara-though he was theologically skilled had to dictate the letters that have been handed down to us because he could not write them himself, is wholly irrelevant for our purposes.

Of course, one cannot-especially with respect to the self-stylization of monks as being simple, illiterate people-take this simply at face value. For us it is sufficient to note however that his illiteracy in no way stood in the way of a career in the Christian church community though of course a former teacher of rhetoric like Augustine could not accept it when people paid heed to such role models while still claiming to understand the scripture.

Until now we have admittedly only looked at ancient Christian manuscripts, as the title of this contribution suggests we will be dealing with, to a very limited degree. Of course information about the ability of bishops and ascetics to write has been recorded in ancient Christian manuscripts but our task here (in accordance with the

26 Garitte 1939, 11-31; Rubenson 1998, 126-132

27 Augustinus, De doctrina Christiana prol. 4 (CChr. SL 32, 2,44-3,53 Martin): Iam vero eorum qui divino munere exsultant et sine talibus praeceptis qualia nunc tradere institui, se sanctos Libros intellegere atque tractare gloriantur, et propterea me superflua voluisse scribere existimant, sic est lenienda commotio ut, quamvis magno Dei dono iure laetentur, recordentur se tamen per homines didicisse vel litteras nec propterea sibi ab Antonio sancto et perfecto Aegyptio monacho insultari debere, qui sine ulla scientia litterarum Scripturas divinas et memoriter audiendo tenuisse et prudenter cogitando intellexisse praedicatur. 
objectives of the special "Material-based text cultures" research field ${ }^{28}$ is to provide access to the phenomenon of reading and non-reading based on the materiality of the text handed down to us and, to this end, in a second part of my paper, I shall look at the materiality of manuscripts. Having argued that, based on the lists of bishops at the (sub-)council of Cyril of Alexandria's party in Ephesus, the behavior of many ancient people might be described as the apostle Paul describes Christian life in general, ${ }^{29}$ i. e. having books as if one did not have them; reading as if one were not reading, it remains for us to strengthen this impression using certain texts (of which many more examples exist) based on the materiality of manuscripts. At a joint conference between the Heidelberg Special Research Centre and our Berlin Special Research Centre "Episteme in Motion" at "Landgut Stober" in Groß Behnitz at the end of June 2017, I expressed the view that, using the example of a biblical text written on a cave chapel of the desert-monastery of St. Theoctistus in South Judea (todays Deir el-Mukalik; fragments now in the Israel Museum Jerusalem) during late antiquity, not everything that looked like a text in Christian antiquity was in fact perceived by all as such. ${ }^{30}$ In order to back up the viewpoint I expressed at the time with additional arguments, I now like to draw on another group of sources (though of course again using just one typical example here). I will supplement such observations with a famous but valuable pamphlet by Adolf von Harnack entitled "Über den privaten Gebrauch der Heiligen Schriften in der Alten Kirche" (On the personal use of the holy scriptures in the Old Church), ${ }^{31}$ which itself builds upon a Göttingen and Berlin work from the late eighteenth and nineteenth century. ${ }^{32}$

To this end, for purely pragmatic reasons, I shall refer to the Berlin Septuagint manuscripts, the majority of which are known to have been collated in 1939 by Otto Stegmüller, later Catholic scholar of religion in Freiburg, and by the Berlin papyrologist Kurt Treu in $1970 .{ }^{33}$ In particular, I would like to look at two special types of manuscripts namely amulets and antiphonal hymns. To this end I shall draw from examples from Berlin but also from Heidelberg too. Incidentally, Adolf Deissmann, later a New Testament scholar in Berlin, was also involved in the first edition of the Septuagint papyri at the university in Badenia. ${ }^{34}$

28 Hilgert/Lieb 2015, 7-16.

29 In 1 Cor. 7:29.

30 Corpus Inscriptionum Iudaeae/Palaestinae IV/1, no. 3166 (p. 554-556, ed. Walter Ameling): lines with quotations of John 3, 5 and 8 together with Matthew 11:28.-My paper on these little fragments will be published soon with some new images.

31 Harnack 1912, cf. now. Gamble 1995, 203-242.

32 Walch 1779. - Cf. also Markschies 2013, 138-145.

33 Stegmüller (ed.) 1939; Treu 1970, 43-65 with images 1-7.

34 Deissmann (ed.) 1905, cf. also Horsley 1993, 35-38.-On Deissmann as papyrologist cf. now Horsley 2019, 66-129, esp.77-81. 


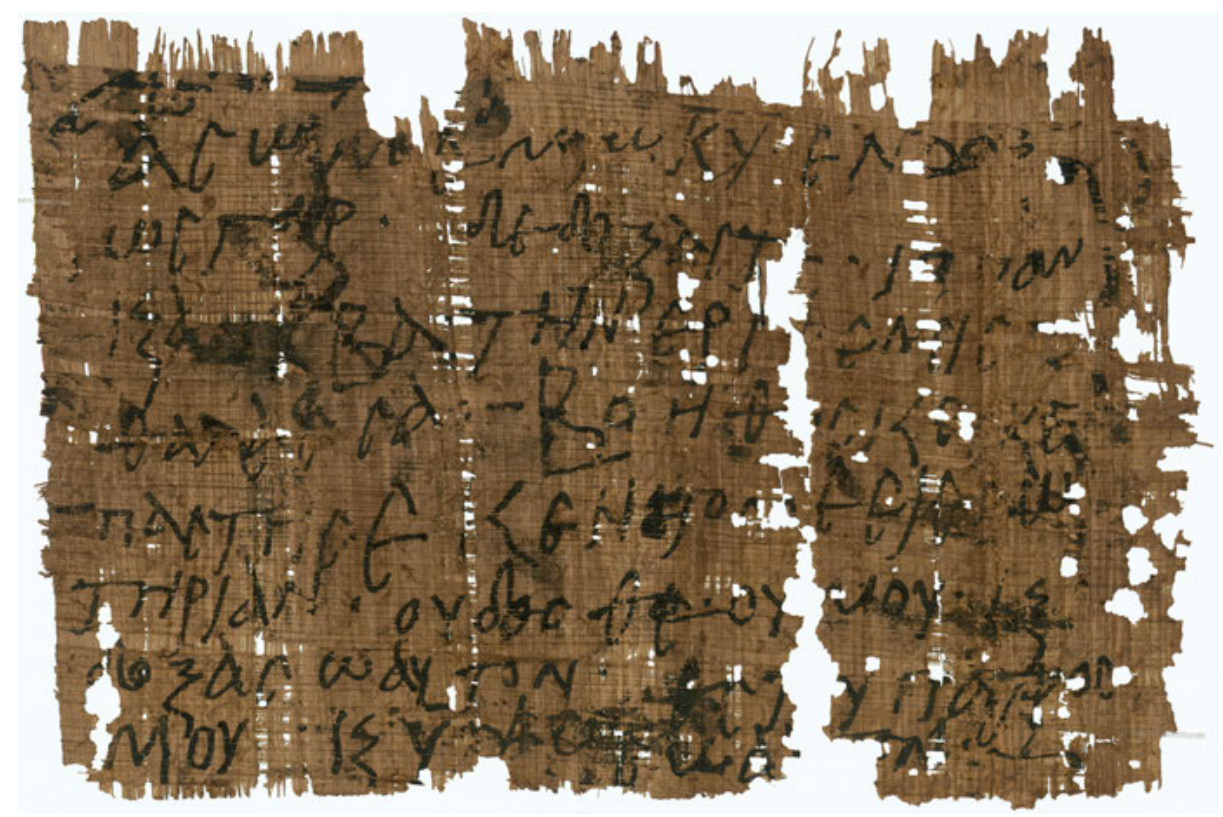

Fig.1: Staatliche Museen zu Berlin, Ägyptisches Museum und Papyrussammlung, Inventar-Nr. P. 16158 R.

To begin with I would like to take a closer look at amulets in this context; thereafter I shall first discuss two Berlin examples, as mentioned. Firstly papyrus 16158 from the sixth century, a single piece measuring $9 \times 13.3 \mathrm{~cm}$ made from "fairly light papyrus". This Berlin sheet contains, in eight short lines, the first two sentences from Exodus 15, the Song of Moses-at the same time the first two lines of the first odes, which have

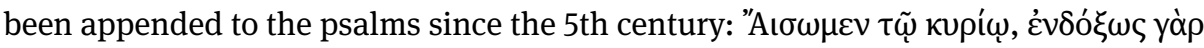

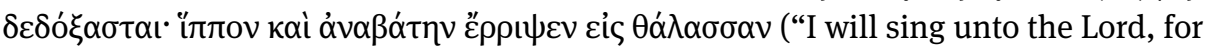
he hath triumphed gloriously: the horse and his rider hath he thrown into the sea"). ${ }^{35}$ The sheet demonstrates distinct signs of folding, meaning it was carried folded together as an amulet rather than being part of a miniature codex. ${ }^{36}$ Understandably wearers were not capable of reading what they were wearing-nor, if they knew it by heart from the liturgy, was there any need for them to. ${ }^{37}$ It is not hard to understand why precisely this Biblical text ended up being used in such a magical context: Wearers, male or female, presuming they knew what it was they were wearing of course, hoped to partake of the $\delta$ v́va $\mu$, the divine strength that cast horse and rider into the sea. With these two lines, they were documenting that they had identified the core

35 Treu 1970, 50: P. 16158, van Haelst 242, Rahlfs 2132; on the text Vattioni 1978, 35-47.

36 Kraus 2004, 485-497.

37 On the "magical use" of such amulets in ancient times and today cf. Versnel 2009, 1- 4. 


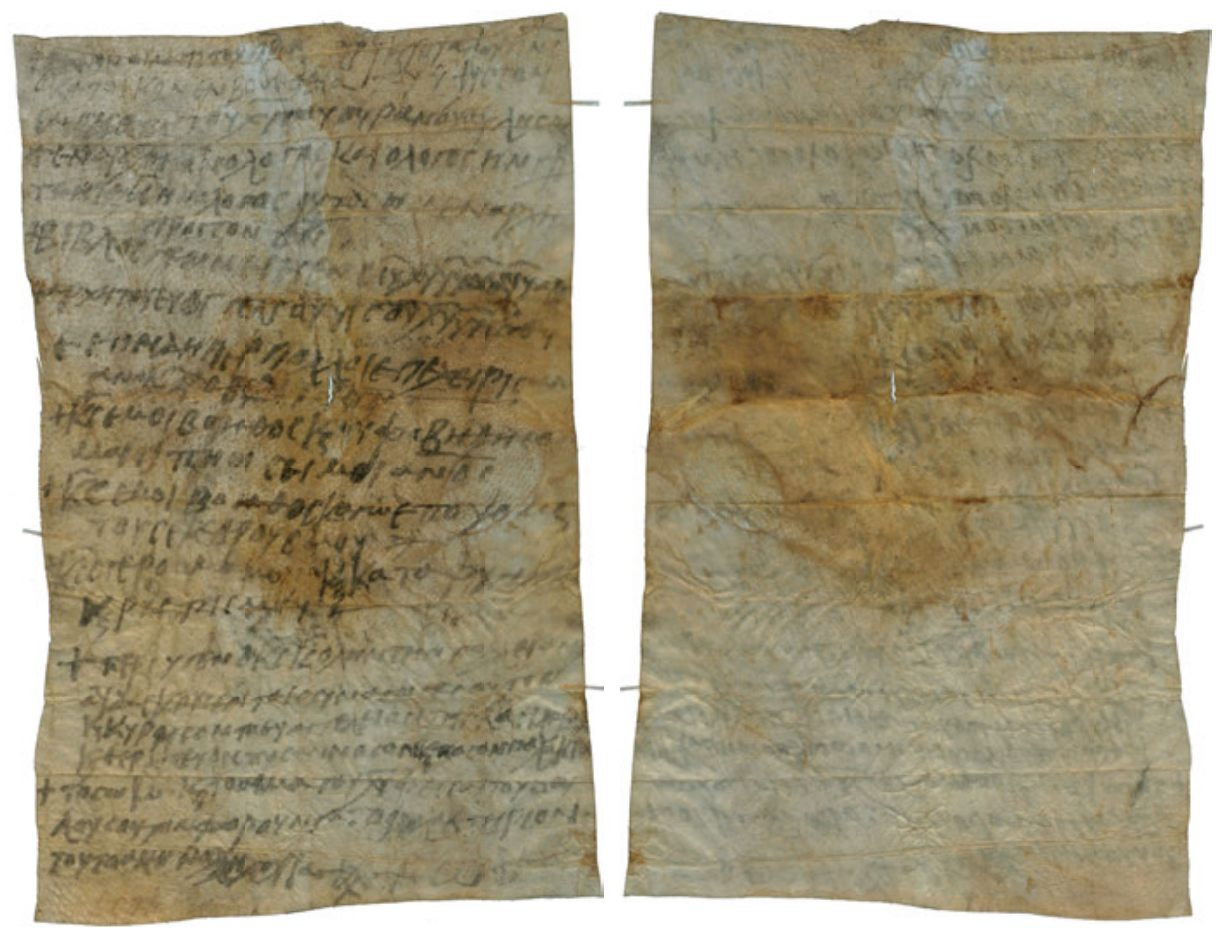

Fig. 2a-b: Staatliche Museen zu Berlin, Ägyptisches Museum und Papyrussammlung, Inventar-Nr. P. 6096.

power in the cosmos and were now wearing this "in black and white" about their person in order to overcome, to paraphrase the title of a splendid book about ancient magic, "harmful magic" 38 and other such monstrosities from day-to-day life through “closeness to God”. Whereas papyrus 16158 cites the biblical text more or less in its canonical form, in other Berlin sections, the biblical manuscripts are far less faithful and have been amended.

Secondly, as an example of biblical texts being treated in this manner, thereby giving rise to a new pseudo-biblical and pseudo-canonical text, I would like to refer to another Berlin amulet from the 6th or 7 th century, papyrus $6096 .{ }^{39}$ This similarly sized piece $(14 \times 8 \mathrm{~cm})$ is a mixed text of 23 lines. It is framed with phrases from the lit-

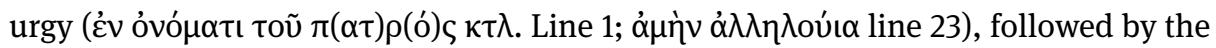

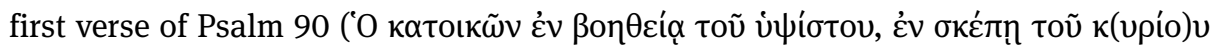

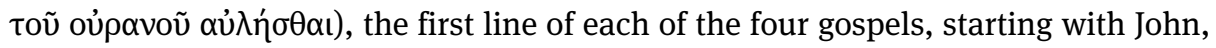
further lines from two various psalms (117,6f.; 17,3) and finally the conclusion: "Body

38 Graf 1996; Wischmeyer 1998, 88-122.

39 Wessely (ed.) 1924, 412 = 188 (Haelst 731 = Rahlfs 2131), cf. also Schmidt/Schubart (eds.) 1910, 129f. and Meyer/Smith 1999, 34f. (no. 9; English translation). 


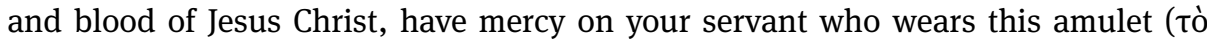

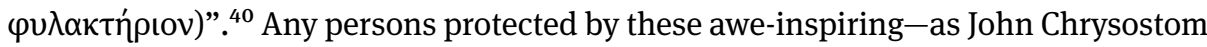
calls them ${ }^{41}$-Eucharistic elements, which they partake of during the mass, the powerful effect of which is enhanced by the glorious phrases on the amulet, resides as

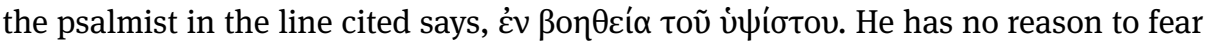
because: What harm can human beings do to him?

Ancient, by their origin sanctified and powerful texts of the Septuagint become a sort of pass of safe conduct and gain an air of concreteness for the individual. They are, as in the liturgical readings, "cut out", a pericope, decontextualised. For the vast majority of users of such compilations, there is no hypertext in which a verse makes reference to its entire former context-in order to establish such links intellectually, one would have had to have been a scholar on the order of an Origen or one of the Cappadocians. It remains decidedly questionable, moreover, whether these amulets were even meant to be read. All considerations that we had reconstructed for the selection of particular Bible verses could just as well have been merely the guiding idea of the writer of the lines; for the reader, the general notion of holding, in the form of the artefact, a certain might and power in one's hands that enabled a proximity to God and power of sorcery, was eminently sufficient. ${ }^{42}$

But this type of re-construction of pseudo-Biblical and pseudo-canonical texts can be found not only in amulets and other transmission contexts devised primarily for private use, but also in liturgical material. ${ }^{43}$ Here one can naturally pose the question as to whether everyone who sang from such manuscripts could in fact read-and if, as Georg Schmelz demonstrated in his work some years ago on church officials in late-antiquity Egypt, even the bishop (in this example: Apa Abraham of Hermonthis in the late sixth century) could not read and write, this is all the more to be assumed of his cantors and singers: "I, Joseph, son of John, humble priest of the holy church of Hermonthis, have written upon instruction, as he cannot write." 44 I shall first address the Berlin single leaf papyrus 11763, a text from the seventh or eighth

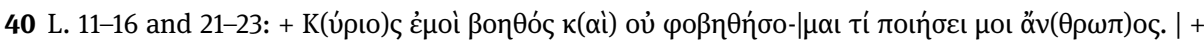

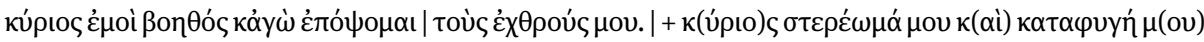

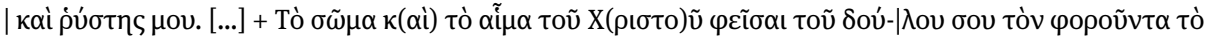

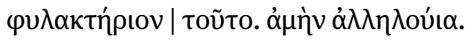

41 Markschies 2016, 420-422.

42 Cf. also Markschies 2017b, 11-35.

43 Markschies 2004, 77-88. Deissmann 1905 has published 27 leafs of what he called "a countryside bible" (P. Heid. Inv. G. 600 resp. VHP I 1 = Rahlfs 919 = Haelst 290 = Aland AT 124 [9]): "Die Derbheit des Papyrus, die mannigfaltigen Versehen des Schreibers und besonders die Nachlässigkeit des Korrektors weisen darauf hin, daß das Buch wohl für eine kleinere und ärmere Kirche geschrieben ist, eine Kirche, deren Theologen von dem Geiste Origineischer Textkritik nicht allzu stark angekränkelt waren. Vielleicht dürfen wir unsere Blätter als die Reste einer ägyptischen Dorfbibel bezeichnen”.

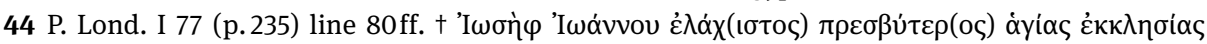

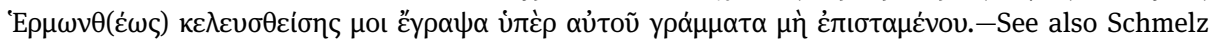
2002, 70-75; Krause, 1969, 57-67. 

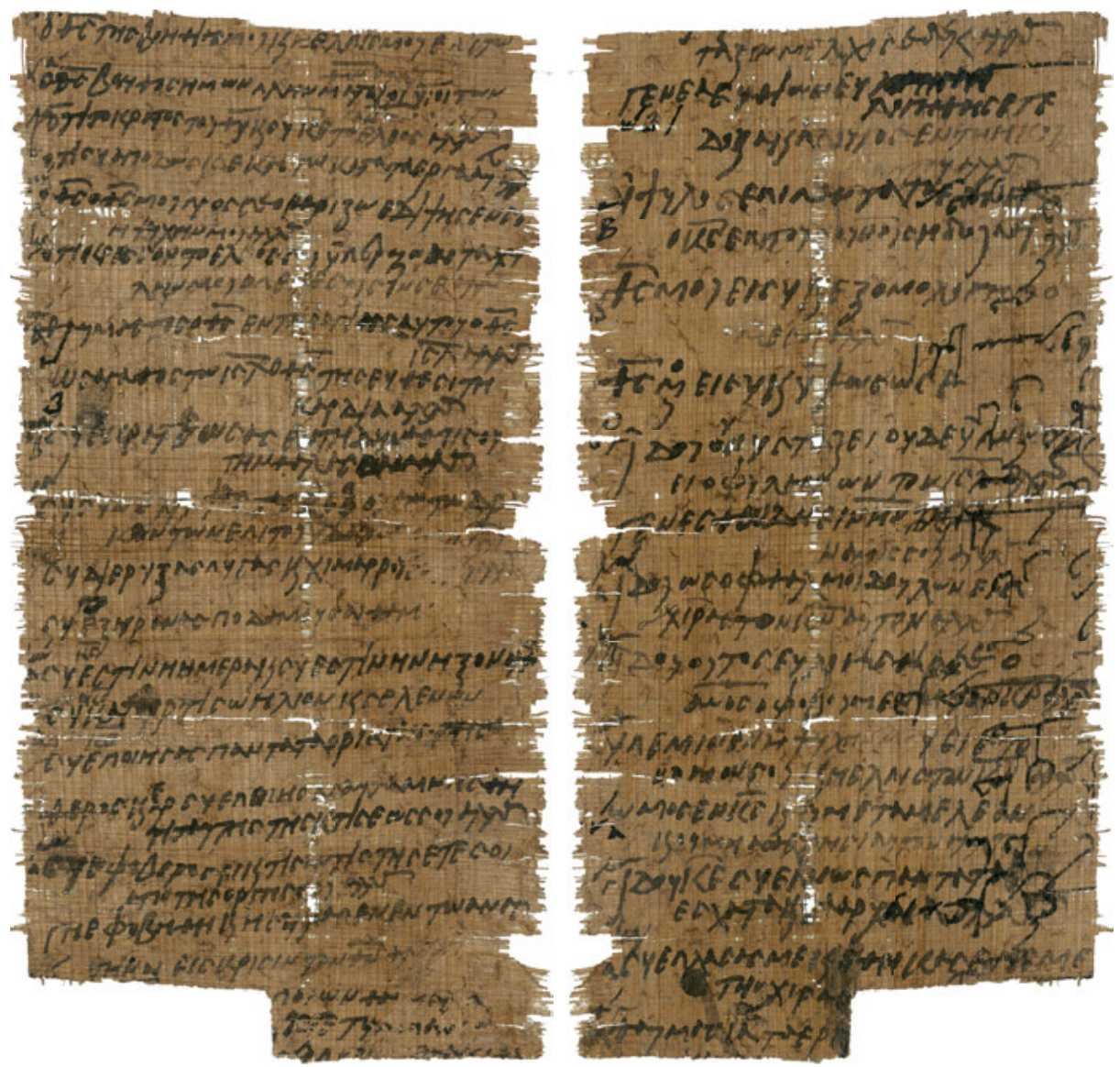

Fig. 3a-b: Staatliche Museen zu Berlin, Ägyptisches Museum und Papyrussammlung, Inventar-Nr. P. 11763.

century, excavated in Hermopolis magna/el-Eschmunen. It is a template for the liturgical antiphonal singing of the Psalms in the (modest) dimensions of $17 \times 8.5 \mathrm{~cm}$; this was noted as early as Stegmüller. At the end of each of the thirty two stanzas of the fragmentary leaf, there is an abbreviated $\dot{\alpha} \lambda \lambda^{\prime}$, signifying $\dot{\alpha} \lambda \lambda \eta \lambda$ ov́t $\alpha$. Excerpts from Psalms 50-150 were evidently originally included; now the transmission begins with

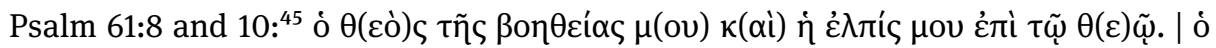

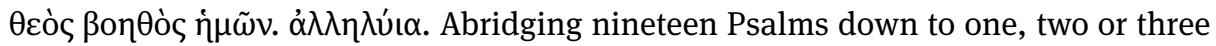
verses in each case, which, moreover, had been taken from completely different places in the Old Testament original (and by no means just from the beginning), ${ }^{46}$

45 Rahlfs 2063 = Haelst 159 = Aland AT 70. The text is edited by Stegmüller 1939, 41-50 (n. 16).

46 Psalm 61:8-10. 13; 62:2. 4; 67:36; 72:1; 73:13. 15-18; 75:8-10; 76:15; 80:3; 109:4; 111:2-3; 112:4; 117:28; 120:4; 121:7; 122:2; 127:4; 129:5-6; 131:11 and 138:5. 14. 
presents a by no means insignificant challenge for a clever epitomator. In view of the linguistic uniformity of some Psalm verses, the following applies here as well: one had-as the monks did, for example-to know the text of the Psalter very well in order to apprehend the constructive character of this antiphonal singing. Conversely, the following also applies, of course: one who could not read, but who had learned such liturgical texts by heart through repeated singing, would not have detected the differences to the authentic Biblical text.

Another means of making texts from the Septuagint "singable" for the antiphonal psalmody of the liturgy through reconstruction is demonstrated by a $12 \times 28.5 \mathrm{~cm}$ leaf from Heidelberg, Papyrus G. 558, from the ninth or tenth century CE. Here we see in Psalm 98 that, after the verses $2 \mathrm{~b}, 5 \mathrm{c}$ and $7 \mathrm{a}$ (taken as three stanzas), the final verse of the entire Psalm is added as a sort of refrain ("hypopsalma"), ó $\theta \varepsilon \dot{\varsigma} \varsigma \dot{\eta} \mu \tilde{\omega} v:+[. .$.

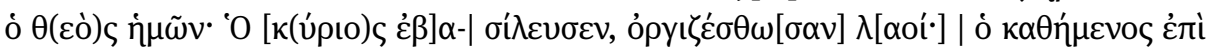

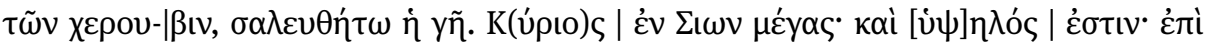

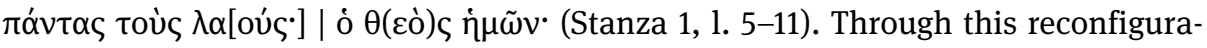
tion, the Psalm is reworked according to the stylistic sensibility of a late-antiquity contemporary and arranged into two shorter and two longer stanzas ${ }^{47}-\mathrm{a}$ procedure as simple as it is effective, and which has already been applied in the Biblical account itself, as can be seen, for example, at the end of the Lord's Prayer. Here again, one has to be liturgically highly experienced or very well-versed in one's regard of the Psalter to even identify the contamination at all, but at the very least able to read. ${ }^{48}$

As my penultimate example, I would like to talk about a Berlin rolled sheet of lead originally from Rhodes $(12 \times 16 \mathrm{~cm})$ and written in the third or fourth century that contains the seventy-ninth Psalm, which was published by Friedrich Hiller von Gaertringen in 1898 and unfortunately is among the unrecovered war losses of the Antiquarium, the current collection of antiquities. ${ }^{49}$ This text (from the hand of a very spare writer), too, must presumably be considered one of the magical texts on account of its material, which was lead. The Psalm was undoubtedly selected for this lead scroll in part because it deals with the special power of the Biblical God, or more

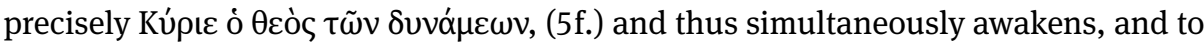
some extent fulfils, the expectation familiar to us from the amulets of a powerful God. In his first edition, Hiller von Gaertringen added the now rather amusing suggestion that the user or person who commissioned it could have been a Rhodian winemaker

47 Kramer/Hagedorn (eds.) 1986, 16-20 = no. 291.

48 Also interesting from the collection in Heidelberg would be P. Heid. Inv. G. 608 a-e $(608 \mathrm{e}=1020$ a) = VBP IV 56 Rahlfs 970 = Haelst 33 = Aland AT 15 [03], cf. Dorn/Rosenberger/Trobisch 1985, 115-121 and ibid. 1986, 106.

49 Miscellanea 8630 (missing): Haelst 177 = Rahlfs 2004; cf. Hiller von Gaertringen 1898, 582-588; Feissel 1984, 230 and Guarducci 1995, 365-368. Cf. also the related digital catalogue of the State Museums of Berlin (last accessed 17.03.2019): http://www.smb.museum/antikebronzenberlin/index.htm s. v. "Misc. 8630 ". 


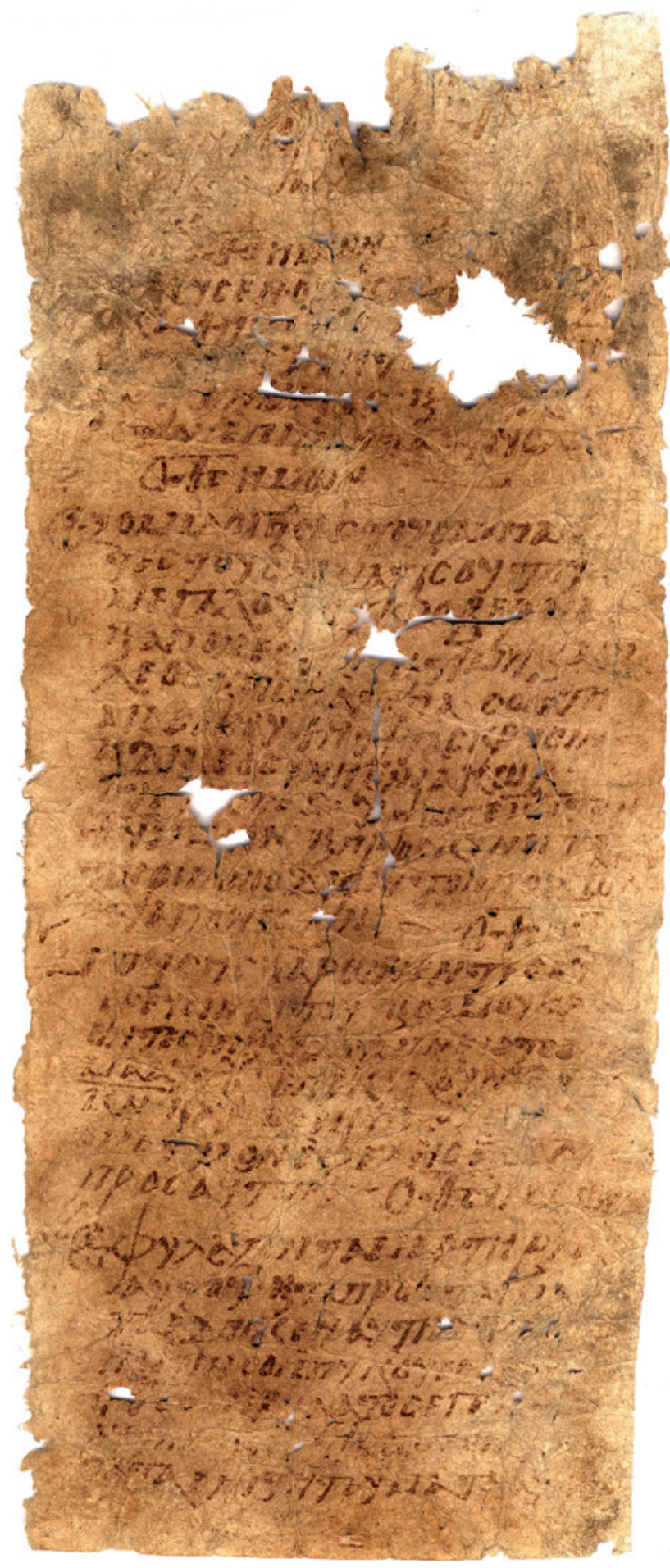

Fig. 4: Universität Heidelberg, Institut für Papyrologie, Inventar-Nr. G. 0558. 


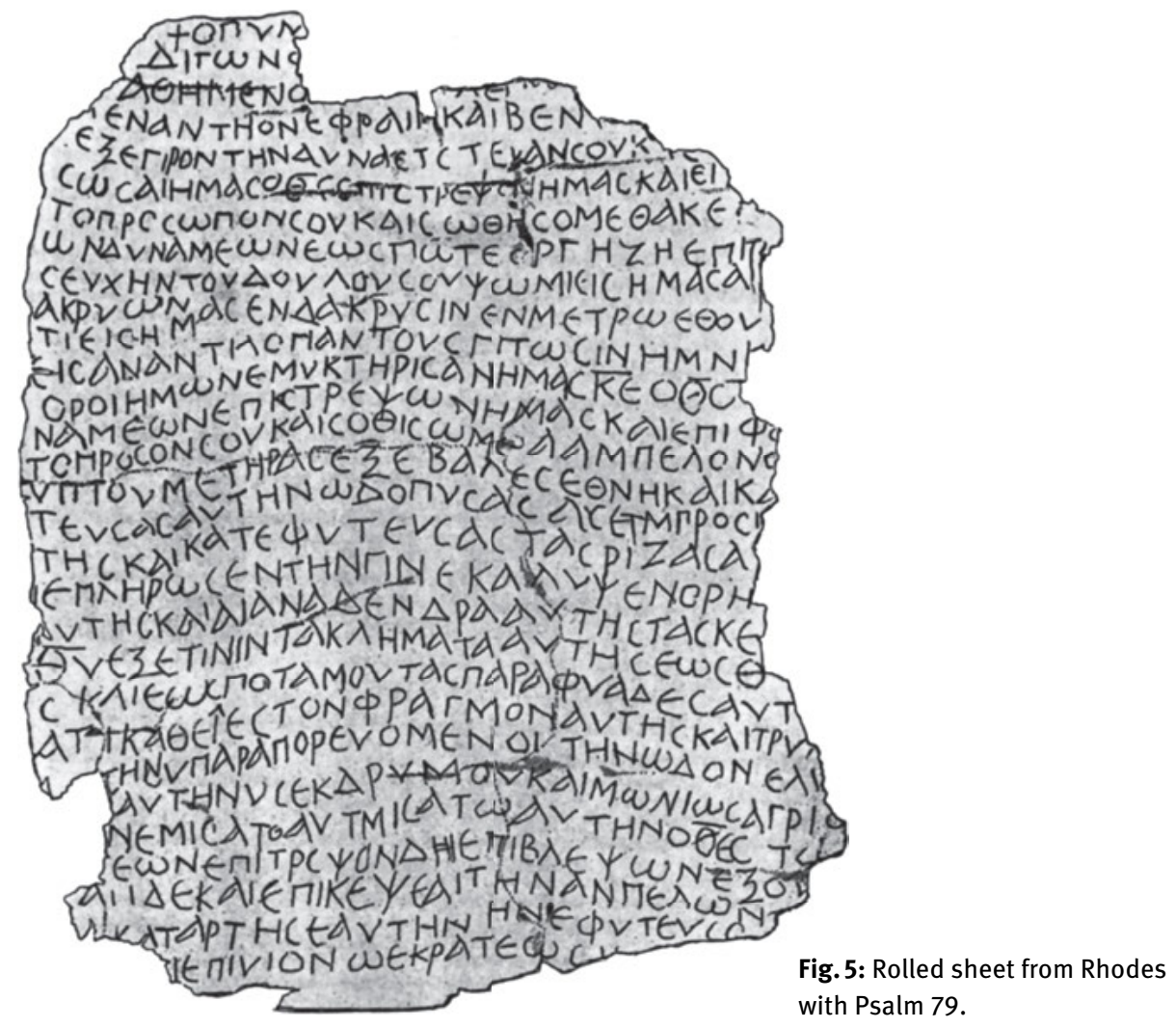

because in the Psalm in question the planting of a vine represents a renewed return of God's favour to his people ${ }^{50}$ and the verse is cited on the lead scroll with this metaphorical formulation. Perhaps. Of course, we don't know that for certain. Yet the idea that such texts comprised of a free arrangement of pseudo-Biblical passages were not compiled entirely on the basis of very general construction principles-as in the ori-

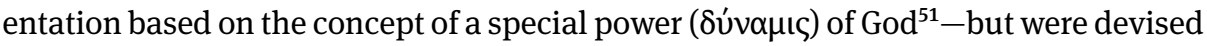
based on the individual profiles of the people who commissioned them, buyers and potential customers of the writer, has a certain plausibility to it. Here again, such observations do not, of course, suggest that the people could, or wanted to, read such texts independently. It seems to me, in this case as well, the rather less probable interpretation of the finding. I would like to note, however, that as long as we do not have a generally accepted typology of the use of such manuscripts in antiquity, any such suggestions must be considered hypothetical.

50 Von Gaertringen 1898, 588. The text is addressed two times in DACL: Jalabert, s. v. "Citations Bibliques dans l'épigraphie grecque,” DACL III/2, p. 1746 with fig. 2990 and Leclercq, s. v. "Plomb,” DACL XIV/1, $1195 \mathrm{f}$.

51 Cf. Markschies 2012, 226-231. 

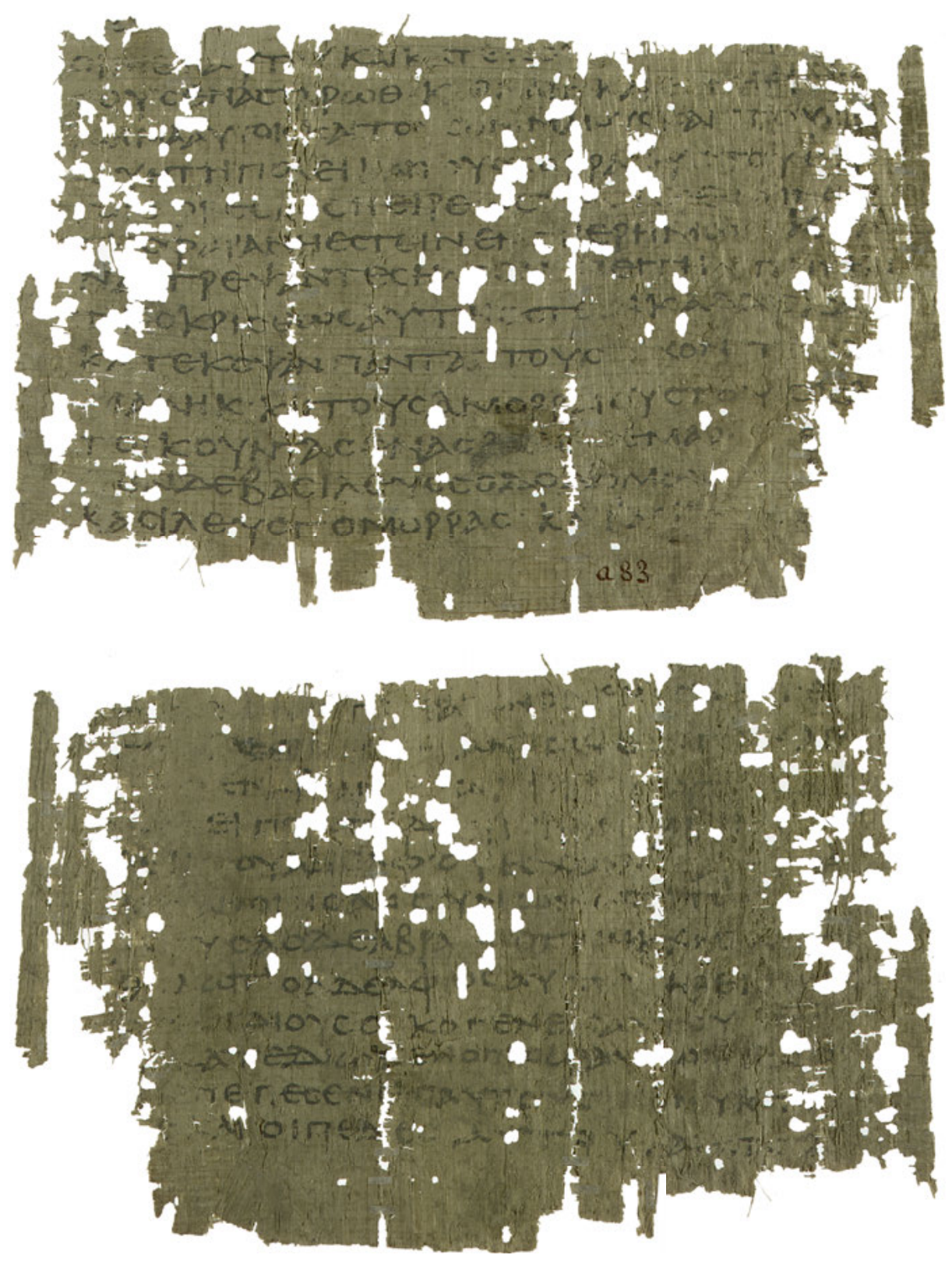

Fig. 6a-b: P. Yale I 1. 
Now I come to the conclusion of this second part of my remarks and briefly address a well-known Genesis papyrus from Yale ${ }^{52}$ in which the verse Genesis 14:14

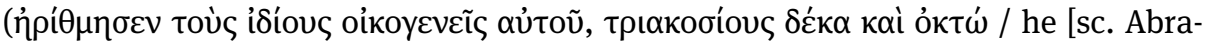
ham] counted his own [slaves] born in his house, three-hundred-eighteen) is cited and the number 318 is written as $\tau$ 1 (verso, line 9)-so probably as first recounted in the Epistle of Barnabas, interpreted as a prefiguration of the cross of Christ. ${ }^{53}$ Now that I have spoken so extensively about the non-reading of texts, I would like to present this writing as an indication of the fact that we have material evidence that people could not only not read texts, but in fact were capable of identifying multiple interpretations or layers of meaning. The elaborately developed hermeneutic process of surveying multiple text interpretations, as we can see for example in Origen, relies on the materiality of the written text as its prerequisite.

We wanted to examine for the Christendom of antiquity to what extent the now widespread concept of "textual communities" is applicable, i. e. "religious communities" which, according to the definition from Brian Stock, "came to understand their identities through the mediation of written texts, which often were interpreted for them by key individuals". ${ }^{4}$ We asked whether the idea that such "textual communities" were constituted as "reading communities" was indeed accurate, or at least approximately so. The observations from the two sections of this presentation do not exactly speak in favour of the model, notwithstanding its wide dissemination. Of course the Christendom of antiquity was also a "religion of the book", but many believers possessed the book as if they did not really have it. They frequently handled the books in liturgy and everyday piety as magical objects or objects of liturgical veneration, but not primarily as texts intended for careful reading. One could be ordained as a priest, as the ordination certificates published by Geog Schmelz demonstrate, ${ }^{55}$ even if one could not read and write-the main thing was that one knew the gospel by heart. Christian communities of antiquity are "textual communities" in the simple sense that they have text, but often have it in a way as if they didn't: "communities of the holy book", but not "reading communities". As usual, the number of those who could not read the holy book and yet prized it above all else cannot be specified with any precision; numbers in antiquity are often more heat than light. But the provocative example of clever bishops who could not read and write and yet were engaged as theological teachers on councils and in congregations should provide ample warning

52 P. Yale I 1 (= Rahlfs 814).-See also Dinkler 1982=1992; Cole 2017, 163f.; Katz 1953.

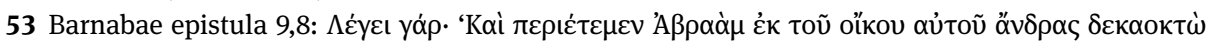

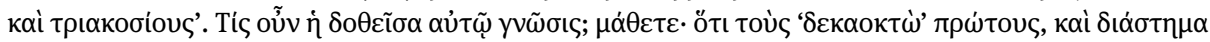

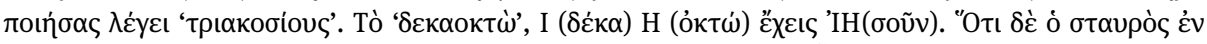

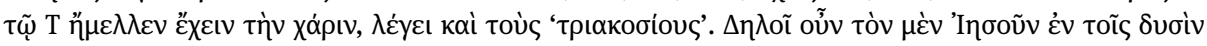

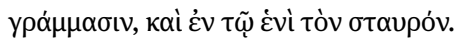

54 Stock 1983.

55 Schmelz 2002, 70-75. 
to us against applying our standards to antiquity. The examination of the material dimension of Christian textual accounts from antiquity with regard to reading and non-reading is-to my mind at least-still in very early days. So it will not come as too much of a surprise if I conclude my preliminary explorations at this point, thank you for your attention and proffer the possibility of a continuation of this fascinating topic as and when the opportunity presents itself.

\section{Bibliography}

Brown, Peter (1993), Die Gesellschaft und das Übernatürliche, Berlin.

Brown, Peter (1995), Macht und Rhetorik in der Spätantike. Der Weg zu einem "christlichen Imperium", München.

Cole, Zachary (2017), Numerals in Early Greek New Testament Manuscripts: Text-Critical, Scribal, and Theological Studies (New Testament Tools, Studies, and Documents 153), Leiden/Boston.

Deissmann, Adolf (ed.) (1905), Die Septuaginta-Papyri und andere altchristliche Stücke (Veröffentlichungen aus der Heidelberger Papyrus-Sammlung 1), Heidelberg.

Dinkler, Erich (1982), “Papyrus Yalensis 1 als ältester bekannter christlicher Genesistext: Zur Frühgeschichte des Kreuz-Symbols (Gen 14:5-8,12-15)", in: Zeitschrift für die neutestamentliche Wissenschaft 73, 281-285 = Dinkler, Erich (1992), Im Zeichen des Kreuzes. Aufsätze, ed. by Otto Merk and Michael Wolter (Beihefte zur Zeitschrift für die neutestamentliche Wissenschaft 61), Berlin/New York, 341-348.

Döring, Klaus (1998), “Menippos aus Gadara”, in: Hellmut Flashar (ed.), Grundriss der Geschichte der Philosophie. Die Philosophie der Antike, Bd. 2/1, Basel, 310-312.

Dorn, H.-J./Rosenberger, Veit/Trobisch, David (1986), “Zu dem Septuagintapapyrus VBP IV 56", in: Zeitschrift für Papyrologie und Epigraphik 61, 115 -121.

Dorn, H.-J./Rosenberger, Veit/Trobisch, David (1985), “Nachtrag zu dem Septuagintapapyrus VBP IV 56", in: Zeitschrift für Papyrologie und Epigraphik 65, 106.

Feissel, Denis (1984), “La bible dans les inscriptions grecques”, in: Claude Mondésert (ed.), Le monde grec ancien et la bible (Bible de tous les temps 1), Paris, 223-231.

Gamble, Harry Y. (1995), Books and Readers in the Early Church. A History of Early Christian Texts, New Haven and London.

Garitte, Gérard (1939), “A propos des lettres de Saint Antoine l'ermite”, in: Le Muséon 52, 11-31.

Graf, Fritz (1996), Gottesnähe und Schadenzauber. Die Magie in der griechisch-römischen Antike, München.

Granatelli, Rosella (1991), Apollodori Pergameni ac Theodori Gadarei testimonia et fragmenta, Rome. Graumann, Thomas (2002), Die Kirche der Väter: Vätertheologie und Väterbeweis in den Kirchen des Ostens bis zum Konzil von Ephesus (431) (Beiträge zur Historischen Theologie 118), Tübingen.

Grube, George M. A. (1959), “Theodorus of Gadara”, in: American Journal of Philology 80, 337-365. Guarducci, Margherita (1995), Epigrafia greca Vol. IV Epigrafi sacre, pagane e cristiane, Rom 1995. Hammerstaedt, Jürgen (1988), Die Orakelkritik des Kynikers Oenomaus (Beiträge zur Klassischen Philologie 188), Frankfurt/Main.

Harnack, Adolf (1912), Über den privaten Gebrauch der Heiligen Schriften in der Alten Kirche

(Beiträge zur Einleitung in das Neue Testament V), Leipzig.

Harris, William V. (1989), Ancient Literacy, Cambridge, MA/London. 
Hilgert, Markus/Lieb, Ludger (2015), “Entstehung und Entwicklung des Heidelberger SFB 933”, in: Thomas Meier, Michael R. Ott u. Rebecca Sauer (eds.), Materiale Textkulturen. Konzepte Materialien - Praktiken (Materiale Textkulturen 1), Berlin/Boston, 7-18.

Hiller von Gaertringen, Friedrich (1898), "Über eine jüngst auf Rhodos gefundene Bleirolle, enthaltend den 80. Psalm", in: Sitzungsberichte der Königlich Preußischen Akademie der Wissenschaften. Philosophisch-historische Klasse 1898, Berlin, 582-588.

Horsley, Gregory H. R. (1993), "An Unpublished Septuaginta Papyrus from the Nachlass of Adolf Deissmann”, in: Archiv für Papyrusforschung 39, 35-38.

Horsley, Gregory H. R. (2019), “Deissmann as Philologist," in: Cilliers Breytenbach and Christoph Markschies (eds.), Adolf Deissmann: Ein (zu Unrecht) fast vergessener Theologe und Philologe (Supplements to Novum Testamentum 174), Leiden/Boston, 66-129.

Jalabert, Louis (1914), s. v. "Citations Bibliques dans l'épigraphie grecque”, in: Dictionnaire d'Archéologie Chrétienne et de Liturgie III/2, Paris, 1731-1756.

Kannengiesser, Charles (2004), Handbook of Patristic Exegesis. The Bible in Ancient Christianity (The Bible in Ancient Christianity 1), 2 vols., Leiden/Boston.

Katz, Peter (1953), “Papyrus Fuad 203 und die Septuaginta [against: Pierre Benoit, „Fragment d'une prière contre les esprits impurs", Revue Biblique 58 (1951), 549-565]", in: Theologische Zeitschrift 9, 228-231.

Kramer, Bärbel/Hagedorn, Dieter (eds.) (1986), Griechische Texte der Heidelberger Papyrussammlung (P. Heid. IV) (Veröffentlichungen aus der Heidelberger Papyrus-Sammlung. NF 5), Heidelberg.

Kraus, Thomas J. (2004), “P.Oxy. V 840-Amulett oder Miniaturkodex? Grundsätzliche und ergänzende Anmerkungen zu zwei Termini”, in: Zeitschrift für Antikes Christentum 8, 485-497.

Krause, Martin (1969), “Die Testamente der Äbte des Phoibammon-Klosters in Theben”, in: Mitteilungen des Deutschen Archäologischen Instituts, Abteilung Kairo 25, 57-67.

Leclercq, Henri (1939), s. v. “Plomb”, in: Dictionnaire d'Archéologie Chrétienne et de Liturgie XIV/1, Paris, 1191-1222.

Markschies, Christoph (2004), "Liturgisches Lesen und die Hermeneutik der Schrift", in: Peter Gemeinhardt and Uwe Kühneweg (eds.), Patristica et Oecumenica. FS für Wolfgang A. Bienert zum 65. Geburtstag (Marburger Theologische Studien 85), Marburg, 77-88.

Markschies, Christoph (2007), “,... für die Gemeinde im Grossen und Ganzen nicht geeignet ...”? Erwägungen zu Absicht und Wirkung der Predigten des Origenes”, in: Christoph Markschies, Origenes und sein Erbe. Gesammelte Studien (Texte und Untersuchungen zur Geschichte der altchristlichen Literatur 160), Berlin/New York, 35-62.

Markschies, Christoph (2012), Das antike Christentum. Frömmigkeit, Lebensformen, Institutionen (C. H. Beck Paperback 1692), 2nd., revised and expanded edition, München.

Markschies, Christoph (2013), "Die Septuaginta als Bibel der Kirche? Beobachtungen aus Vergangenheit und Gegenwart”, in: Reinhard Gregor Kratz and Bernd Neuschäfer (eds.), Die Göttinger Septuaginta. Ein editorisches Jahrhundertprojekt (Abhandlungen der Akademie der Wissenschaften zu Göttingen. Neue Folge 22), Berlin/Boston, 235-254.

Markschies, Christoph (2016), "Current Research on the Eucharist in Ancient Christianity-How the Eucharist developed from the End of the 4th Century in East and West", in: Early Christianity 7, 417-446.

Markschies, Christoph (2017a), "Politische Dimensionen des homöischen Bekenntnisses? Oder: Ursacius und Valens in Sirmium 359 n. Chr.”, in: Uta Heil and Jörg Ulrich (eds.), Kirche und Kaiser in Antike und Spätantike, Festschrift für Hanns Christof Brennecke zum 70. Geburtstag (Arbeiten zur Kirchengeschichte 136), Berlin/Boston, 111-130. 
Markschies, Christoph (2017b), “Demons and Disease”, in: Jared Secord, Heidi Marx-Wolf and Christoph Markschies (eds.), Health, Medicine, and Christianity in Late Antiquity (Studia Patristica 81), Leuven/Paris/Bristol, CT, $11-35$.

Meier, Mischa (2011), “'Ein dogmatischer Streit' - Eduard Schwartz (1858-1940) und die 'Reichskonzilien' in der Spätantike", in: Zeitschrift für Antikes Christentum 15, 124-139.

Meyer, Marvin W./Smith, Richard (1999), Ancient Christian Magic. Coptic Texts of Ritual Power, Princeton, NJ.

Meyer, Paul M. (1916), Griechische Texte aus Ägypten herausgegeben und erklärt. I. Papyri des neutestamentlichen Seminars der Universität Berlin. II. Ostraka der Sammlung Deissmann, Berlin.

Nongbri, Brent (2018), God's Library. The Archaeology of the Earliest Christian Manuscripts, New Haven and London.

Roberts, Colin H./Skeat, Theodore C. (1983), The Birth of the Codex, New York.

Rubenson, Samuel (1998), The Letters of St. Antony. Monasticism and the Making of a Saint (Studies in Antiquity \& Christianity), Minneapolis.

Schmelz, Georg (2002), Kirchliche Amtsträger im spätantiken Ägypten nach den Aussagen der griechischen und koptischen Papyri und Ostraka (Archiv für Papyrusforschung. Beiheft 13), München/Leipzig, 70-75.

Schmidt, Carl/Schubart, Wilhelm (eds.) (1910), Altchristliche Texte (Berliner Klassikertexte. Heft VI), Berlin.

Stegmüller, Otto (ed.) (1939), Berliner Septuagintafragmente (Berliner Klassikertexte. Heft VIII), Berlin (= Diss. phil. Berlin 1938).

Stock, Brian (1983), The Implications of Literacy: Written Language and Models of Interpretation in the Eleventh and Twelfth Centuries, Princeton.

Treu, Kurt (1970), “Neue Berliner Septuagintafragmente”, in: Archiv für Papyrusforschung 20, 43-65.

Vattioni, Franceso (1978), “Il canto di Mosè (Es. 15,1-19) nei papiri e nella Vetus Latina”, in: Studia Papyrologica 17 (1978), 35-47.

Versnel, Hendrik S. (2009), Fluch und Gebet: Magische Manipulation versus religiöses Flehen? Religionsgeschichtliche Betrachtungen über antike Fluchtafeln (Hans-Lietzmann-Vorlesungen 10), Berlin/New York.

Walch, Christian Wilhelm Franz (1779), Kritische Untersuchung vom Gebrauch der heiligen Schrift unter den alten Christen in den vier ersten Jahrhunderten, Leipzig.

Weber, Thomas Maria (2002), Gadara - Umm Qēs. Vol.1: Gadara Decapolitana. Untersuchungen zur Topographie, Geschichte, Architektur und Bildenden Kunst einer "Polis Hellenis" im Ostjordanland (Abhandlungen des Deutschen Palästina-Vereins 30), Wiesbaden 2002.

Weckwerth, Andreas (2010), Ablauf, Organisation und Selbstverständnis westlicher antiker Synoden im Spiegel ihrer Akten (Jahrbuch für Antike und Christentum. Ergänzungsband. Kleine Reihe 5), Münster.

Wessely, Charles (ed.) (1924), Les plus anciens monuments du Christianisme. Écrits sur papyrus (Patrologia Orientalis 18,3=88), Paris.

Wischmeyer, Wolfgang (1998), “Magische Texte. Vorüberlegungen und Materialien zum Verständnis christlicher spätantiker Texte”, in: Johannes van Oort und Dietmar Wyrwa (eds.), Heiden und Christen im 5. Jahrhundert (Studien der Patristischen Arbeitsgemeinschaft 5), Löwen, 88-122. 


\section{Photo Credits}

Fig.1, 2a-b, 3a-b: Staatliche Museen zu Berlin, Ägyptisches Museum und Papyrussammlung, Scan: Berliner Papyrusdatenbank.

Fig. 4: Universität Heidelberg, Institut für Papyrologie.

Fig. 5: Louis Jalabert, s. v. “Citations Bibliques dans l'épigraphie grecque,” DACL III/2, p. 1746, fig. 2990.

Fig. 6a-b: Beinecke Rare Book \& Manuscript Library, Yale University, General Collection, P.CtYBR inv. 419. 